\title{
THE WAGE-EARNER AND THE PRISON WORKER
}

\author{
By John Mitchell, \\ Seventh Vice-President, American Federation of Labor, and \\ President International Mine Workers.
}

Organized labor is the strongest and most persistent advocate of the employment of convicts in the prisons upon those commodities which are needed by the state and its subdivisions for consumption in its several institutions and departments. The charge that the labor unions are opposed to convict labor is a malicious attempt to prejudice the public against unionism by shifting upon the unions the responsibility for the evil conditions existing in the penal institutions. ${ }^{1}$ These are not the words of any labor official, uttered either in complaint or as a boast. They are set down as one of the findings of one who has investigated the convict contract labor system in this country.

One-sided indeed has the conflict so often been that tradeunionists in many states in which the pernicious system has been carried on have accepted the fact, as a matter of course, that obstacles to their attempts to abolish it should be the sentiments of those philanthropically inclined but short-sighted, the emotional utterances of persons reflecting an uninformed public opinion, and, naturally, the special pleadings to the public, accompanied by underhand machinations, of the two classes of men directly controlling the labor of the prisoners-namely, contractors and prison managers.

That is assumed to be the criminal selfishness of the tradeunionists in demanding for themselves the work performed by prisoners, the grievous wrong done to convicts in keeping them idle in their cells, the sufferings of their families when deprived of even the little wages they might earn during their terms of confinement, the certainty of the convict falling into temptation when released at the end of his term without the pittance he might have saved if kept at work on wages, the serious injury to society caused by turning loose upon it annually hundreds or even thousands of desperately 1912.

1 E. Stagg Whitin. "Trade Unlons and Prison Labor," in Case and Comment, September, 
impoverished criminals ignorant of any means of making an honest living, whereas they might have been instructed in good trades while in prisons - on these themes have been written editorials, sermons, political speeches, and college men's theses, until it might seem that on this question all the rest of the world were in unison against the trade-unionists. This, however, was never really the fact. There has always been on the side of the unionists a considerable body of men, many of them penologists, who had given sufficient study to the complicated subject of prison labor to be entitled to pronounce upon it a well-founded opinion.

When, three years ago, the National Committee on Prison Labor entered upon its work, it was found that its members were in practical agreement on the question with the trade-unionists, that sentiment among active legislators and other public leaders had been changing as guided by a knowledge of the subject, and that hopes to lift our prison labor systems up to a plane that would respond to the demands of the enlightened judgment of competent penologists were reasonably well founded.

"After one year of study the National Committee on Prison Labor found the preponderance of evidence to be in favor of the stateuse system; after a second year of study and further investigation, the committee is in a position to declare as prejudicial to the welfare of the prisoner, the prisoner's family and the public, the contract system of prison labor. The committee, therefore, declares itself opposed to the contract system of prison labor and to every other system which exploits his labor to the detriment of the prisoner."2 With time, this group has been steadily reinforced by independent investigators and disinterested readers of their reports.

The present comparatively advanced status of the movement to bring prison labor in America into accordance with methods approved by European authorities on the subject, may be attributed in good part to the views of the backwardness of our practices expressed by foreign delegates to the International Prison Congress held in Washington last year. The president of that congress said of America's prisons: "In these jails it is hardly too much to say that many of the features linger which called forth the wrath and indignation of the great Howard at the end of the eighteenth century." The laws passed at the sessions of a number of our state legislatures last

IPrison Labor Bulletin, March, 1912. 
winter providing for changes in prison labor were in themselves admissions of sad deficiencies in the methods heretofore pursued.

It may perhaps be said that at length the tide has turned and that the public is gradually coming to recognize the correctness of the position of the trade-unionists with respect to prison labor. Assistance is coming to them in putting an end to a most unhappy situation, whether one considers factors in it which affect the prisoner, the free laborer or the community.

It is natural for the reader to ask why it can be affirmed positively that the trade-unionists have been in the right on this question when so many other well-intentioned citizens who regarded themselves as well informed on public questions were in the wrong. The reply is that union men, especially those of certain occupations, on being for years brought constantly and intimately in contact with the economic and social consequences of contract prison labor, were driven by merciless necessity to find a just solution of the problem involved in it as a national disgrace and social injury.

Iron molders, cigar-makers, boot and shoe makers, chairmakers and other furniture workers, shirt-makers and other garment workers, harness-makers and other leather goods workers, as well as wage-earners in a goodly list of other indoor occupations, at one time or other and in one state or other, during a long period, have had driven home to them through contract prison labor a lesson in political economy which many good people not wage-workers, viewing the question sentimentally rather than practically, could have little opportunity to learn. Only a faint impression may be gained when one reads in an encyclopedic work on abstract economics such a dictum as:

"The price of a surplus of a commodity in a market is the price of the entire stock," but a deep and lasting impression is received, as from a knock-out blow, by a force of "free" dollar-a-day girl shirt-waist makers when they are discharged because the goods turned out from their employer's factory cannot compete in market price with goods of the same kind produced for a prison labor manufacturer by twenty-cents-a-day convicts. On this economic point, the New York Commissioner of Labor has thus quoted a shirt manufacturer: "All goods are sold by commercialism, and the lowest price makes the price for all as long as the cheaper article is on sale."'

sNew York State Commissioner of Labor Report 1909. 
In his report for 1910, the Commissioner of Labor of Missouri gives the idea clearly when he says: "A bad feature for the outside manufacturer is that convict goods can be and are sold to dealers and jobbers at figures slightly below their own. Therefore, it is very plain that all prison-made articles stand a better chance of selling first, and the demand must exceed this output before the jobbers and dealers can begin to handle the products of the regular taxpaying factories employing honest wage-earning men and women."

In Missouri alone in 1909 the output of convict labor shops was valued at $\$ 4,708,102.4$ Now, it is by far the lesser factor in the problem for that state that nearly seventeen hundred free industrial wage-earners were in that year thrown out of work through the contract labor of that number of prisoners, with a loss to free labor of $\$ 758,000$ in wages, as computed by the commissioner. The portentous factor to society was the demoralization of the markets through the prison-labor goods, with ruinous consequences to the free-labor manufacturers, necessitating low wages for their employees and perhaps the temporary or even permanent closing of factories. When one remembers that the case of Missouri is the case of every state tolerating the convict contract system, in all twenty-nine a year ago, he may see the enormity of the wrong done in $t$ se United States to the wage-workers who are not convicts and to the manufacturers who are not privileged to have their goods made by convicts in prison factories, with the advantages of free rent, power and heat, and an untaxed plant.

Left to themselves, the free manufacturers in an industry can in a general way so conduct it as either to minimize the occasional waste from over-production or to overtake the market on the occurrence of a shortage in production. In the course of years they can maintain approximately an equilibrium of trade, resulting on the whole in fairly steady work for the wage-earners and average gains to the investors in the business. But, to a number of industries, of all the circumstances which vitiate the natural course of free production, prison labor has long been one of the most hurtful and vexatious. Fully thirty years ago the stove manufacturers of New York, in petitioning the legislatures to do away with iron molding in Sing Sing, represented that as a body they could, if the state took its hands off them, provide for the average annual consumption of their goods

'Missourt Red Book, 1909, pp. 457-8. 
at remunerative prices, without serious fluctuation in their scale of wages or their number of employees. Contract prison products, however, made the total output and its market prices ruinously uncertain. In New York, the contest between the two classes of metal manufacturers, free and prison, ran through decades. It was largely the efforts of the molders' union, associated with other labor organizations, which brought about the constitutional amendment of 1895 , by which was introduced what is now known as the "Stateuse" system, putting an end in New York to contract prison labor.

A barbarous social abuse certain to arise from the establishment of contract prison labor lies in securing the needed laborers. It would not do to have the contractors suffer through want of employees. A significant light was thrown on this phase of the subject in testimony given at Washington before a sub-committee of the House of Representatives three years ago, relative to a report of the Baltimore grand jury in January, 1907. A passage in this report read: "Owing to the high value of labor, we find the authorities of our penal institutions anxious for long-term prisoners, in order that their financial showing shall be improved and that they may get appropriations for new buildings, on the ground of their being entirely or partially self-supporting. This is very commendable."5 The Maryland penitentiary is one of the shirt trust factories. The process of legally putting poor and ignorant black men to work in the southern mines as convict laborers has all the look of a villainous form of conscription.

"The report on the State Convict Board of Alabama shows that the total gross earnings of convicts in that state for the year ending September 10 th was $\$ 1,073,286.16$. These figures, without taking into account the earnings of one hundred convicts who were employed on the state farm, from whom the state would have received $\$ 30,000$ more if they had been leased on the same terms as the others, shows a gain for 1912 over the previous year of $\$ 16,456.93$. The figures for other states where the convict lease system is in force are not at hand, but there is every reason to believe that the above is a fair sample of the profits made elsewhere. No dou'st this statement of the Convict Board, coming at the time of the year when the papers are filled with the reports of bountiful harvests and bumper crops,

5 Hearings before Sub-Committee No. 4, Committee on Labor, House of Representatives on H. R. 4040, "Competition of Penal Labor" (1908), p. 127. 
will read to a good many people like another evidence of the prosperity of the state. Other persons, considering the dubious source of this income, will perhaps comfort themselves with the reflection that the profits of the state upon its convicts go very largely to support the public schools, and so return good for evil. How many know or have considered the actual facts in regard to the matter, namely, that under the fee system, as it still exists in Alabama and other parts of the South, the sheriff is put in the position of a recruiting agent for the employers of convict labor; that about eightyseven per cent of all convicts of the state are negroes, many of whom, arrested for trifling offenses, have drifted into crime because of ignorance and the neglect of the state properly to educate them; that in spite of the regulations to protect these unfortunate slaves of the state, life in the convict camps to-day is more degrading and cruel than it ever was under the worst form of slavery; that when these men are finally released they go back into the walks of daily life broken in body and embittered in mind, to become not only a burden but a menace to the remainder of the community? Considered in the light of its ultimate results to the community, this large profit from convicts' labor is not a gain-not even in the material sensebut a loss. A few private individuals may profit by this system, but the state loses. The state loses because these men from the convict camps and the mines return, at the end of their period of servitude, worse in body and in soul than they were before. No state can afford to make a business profit out of the moral degradation of any of its citizens." 6

How many men and women of the needle trades in the United States, it may be asked, have seen their jobs taken from them through prison labor-just as the employees of four shirt factories in Baltimore, after the panic of 1907 , were discharged, doomed to idleness, when the firm employing them transferred their sewing machines to the Maryland penitentiary, to give the prisoners work at full time? How many industrial wage-workers have seen the places of their employment close through their employer's inability to compete with a manufacturer working convicts-just as was the case of a chair-making company, which, after thirty years in the business, was forced to discontinue turning out a certain grade of goods made for it by free employees at $\$ 1.50$ to $\$ 3.00$ a day, in competition with convicts at 30 to 50 cents a day? How many poor, unfortu-

- The Oullook. December 7. 1912. 
nate blacks and whites have known while at work in prison or mine that they have been arrested, not to be punished as law-breakers, but to be worked for a combination of prison keepers and slavedriving prison labor contractors-just as may be the case to-day whenever the temptation and the power exist for treacherous authority and unscrupulous greed to seize and exploit weakness and helplessness? Thousands, even tens of thousands, of American citizens have in one or other of these ways been mercilessly and infamously robbed of their time, of their labor, either of which means so much of their very lives. All these sufferers had relatives, or friends, or fellow-workers who witnessed their cruel and unjust fate or heard the story of it, and these, with the victims, have no doubt wondered, in righteously rebellious spirit, where were law and justice and mercy and Christianity, while such shocking evils could be tolerated by society.

Is there a confirmed criminal class in this country, skeptical of purity in the law and beneficence in its institutions? Is there a growing defiance of the public officials? Is there a widespread conviction among the lowly that to be poor is to be legitimate prey for cunning arch-thieves cloaked in legal authority or endowed with legal privileges, even to that of jailing the victims of poverty and working them like slaves?

When one calls to mind the enormous numbers of poor people who have suffered in some form from the blunders or the criminalities possible under our prison labor systems, something of the answer to a perplexing question which law-abiding wage-earners ask one another is suggested. The question is: Who are the mob-makers that suddenly appear in our cities in times of popular excitement? Who are the missile throwers and violent shouters of incendiary phrases, usually unknown to the unionists, that during a lockout or a strike make for the thick of the crowds, to act contrary to the wishes and instructions of the union? To what extent may lawless outbreaks be due to the irrepressible sense of wrong done him by society rankling in the breast of here one man and there another, feeding the latent mob spirit to flame up with the opportunity of manifesting it in public? It is to be remembered that on January 1, 1911, the total prison population of the United States was more than one hundred thousand, while the total number sent to prison in the course of the year 1910, for short as well as long terms, was more than four hundred thousand. 
As to a highly promising, if not yet thorough, reform in prison labor, the principle has been applied in New York for fifteen years. Pursuant, as already mentioned, to the petitions of trade-unionists and citizens who coincided with their plan, the Constitutional Convention of 1894 adopted an amendment providing that only such goods should be made in the prisons as were to be used in the public institutions of the state and its subdivisions. The August, 1911, issue of the "Prison Labor Bulletin" of the National Committee on Prison Labor, in announcing a forthcoming complete report of the status of New York's prison industries, says it will show that under the "State-use" system the prison population cannot, even with greatly increased efficiency, come anywhere near supplying the market which the law has thus provided for prison made goods. ${ }^{7}$ In addition, at the Onandaga penitentiary, the stone quarry is to be so developed as to supply sufficient work all the year round for the convicts there.

Here we have methods for employing prison labor which have been shown through practice to be productive, as nearly as possible, of unmixed good, viz., manufacturing articles to be used in public institutions and breaking stones for road-making. Further, some states have successfully employed convicts in making roads.

It is now generally believed that convicts should be paid for their labor and that a part of their wages should go to their families. With these features the New York program, supplemented by road-making, presents the leading requisites of an effective salutary scheme. Under it, prisoners may be self-sustaining, as presumably they were, on the whole, while at liberty. The suffering of those dependent upon them may be alleviated through a part of their wages. The prison products do not disturb the markets, the effect of supplying the public institutions amounting only to a slight restriction of the selling field for certain manufacturers. The factory wage-workers are not exposed to convict competition. The convicts may be kept steadily at work, while undergoing a helpful manual training. Limitations are set to the temptations, or opportunities, on the part of prison superintendents, wardens, commissioners-of whatever title-for a vile and cowardly graft. Manufacturers operating their own plants are rid of a discreditable class of competitors.

I Pinal Report. Commission to Examine the Department of State Prisons, New York, 1911. 
The change in public sentiment is indicated by the legislation on the prison labor problem in 1911. No state this year has given new powers of leasing or contracting for convict labor. Only one has extended the field of its lessees. Twenty-one have made some provision for state operation or assumption of industries. Eight have provided for state consumption, six for regulation of prices and standardization of products, and three for the branding of prisonmade articles. Nine have authorized road-making or road-stone cr shing by convicts. Provision for radical changes in the methods of administration was made in seven states. ${ }^{8}$ The principle of relief for dependent families of prisoners was given some recognition. All told, a good start was made in the right direction.

Organized labor, $t$ te most forceful social element in promoting these-reforms, can welcome such opinions on prison labor as the following, given editorially in the employers' Mines and Minerals for June: "There is no question but that convicts should be made to work, and at least earn their keep and the expense of maintaining the penal institutions, if the products of their labor do not enter into competition with those of free labor. There is a kind of work they can do, and it is work that interferes least with free labor. They can crac's stone in the priscn or jail yards, and this cracked stone can be effectually used to make, repair and keep in order the public roads. If each state should put its prisoners to such use, it would materially reduce the just complaints against our abominable roads; and besides, the privileges and rights of free, honest labor would be interfered with less than by any other work."

It is true, with regard to prison labor, as of many another social problem, that in defending themselves trade-unionists have been protecting not only the interests of non-unionists but of society in general.

- E. Stagg Whitin, Penal Servitude, p. 8. 